\title{
Midkine is a NF- $\kappa$ B-inducible gene that supports prostate cancer cell survival
}

\author{
Zongbing You*1,5, Ying Dong1, Xiangtian Kong2, Laurel A Beckett ${ }^{3}$, \\ Regina Gandour-Edwards ${ }^{4}$ and Jonathan Melamed ${ }^{2}$
}

\begin{abstract}
Address: ${ }^{1}$ Department of Orthopaedic Surgery, University of California, Davis, Sacramento, CA 95817, USA, ${ }^{2}$ Department of Pathology, New York University School of Medicine, New York, NY 10016, USA, ${ }^{3}$ Department of Public Health Sciences, Division of Biostatistics, University of California, Davis, Sacramento, CA 95817, USA, ${ }^{4}$ Department of Medical Pathology and Laboratory Medicine, University of California, Davis, Sacramento, CA 95817, USA and ${ }^{5}$ Department of Structural \& Cellular Biology and Tulane Cancer Center, Louisiana Cancer Research Consortium, School of Medicine, Tulane University, New Orleans, LA 70112, USA
\end{abstract}

Email: Zongbing You* - you.zongbing@gmail.com; Ying Dong - yddong@ucdavis.edu; Xiangtian Kong - kongx03@med.nyu.edu; Laurel A Beckett - labeckett@ucdavis.edu; Regina Gandour-Edwards - regina.gandour-edwards@ucdmc.ucdavis.edu; Jonathan Melamed - Jonathan.Melamed@nyumc.org

* Corresponding author

Published: I4 February 2008

BMC Medical Genomics 2008, I:6 doi:10.1 186/1755-8794-I-6

This article is available from: http://www.biomedcentral.com/l755-8794///6

(C) 2008 You et al; licensee BioMed Central Ltd.

This is an Open Access article distributed under the terms of the Creative Commons Attribution License (http://creativecommons.org/licenses/by/2.0), which permits unrestricted use, distribution, and reproduction in any medium, provided the original work is properly cited.
Received: 10 February 2007

Accepted: 14 February 2008

\begin{abstract}
Background: Midkine is a heparin-binding growth factor that is over-expressed in various human cancers and plays important roles in cell transformation, growth, survival, migration, and angiogenesis. However, little is known about the upstream factors and signaling mechanisms that regulate midkine gene expression.

Methods: Two prostate cancer cell lines LNCaP and PC3 were studied for their expression of midkine. Induction of midkine expression in LNCaP cells by serum, growth factors and cytokines was determined by Western blot analysis and/or real-time quantitative reverse-transcription - polymerase chain reaction (RT-PCR). The cell viability was determined by the trypan blue exclusion assay when the LNCaP cells were treated with tumor necrosis factor alpha $(T N F \alpha)$ and/or recombinant midkine. When the LNCaP cells were treated with recombinant midkine, activation of intracellular signalling pathways was determined by Western blot analysis. Prostate tissue microarray slides containing 129 cases ( 8 normal prostate tissues, 40 early stage cancers, and 7 I late stage cancers) were assessed for midkine expression by immunohistochemical staining.

Results: We identified that fetal bovine serum, some growth factors (epidermal growth factor, androgen, insulinlike growth factor-I, and hepatocyte growth factor) and cytokines (TNF $\alpha$ and interleukin-Ibeta) induced midkine expression in a human prostate cancer cell line LNCaP cells. TNF $\alpha$ also induced midkine expression in PC 3 cells. TNF $\alpha$ was the strongest inducer of midkine expression via nuclear factor-kappa B pathway. Midkine partially inhibited TNF $\alpha$-induced apoptosis in LNCaP cells. Knockdown of endogenous midkine expression by small interfering RNA enhanced TNF $\alpha$-induced apoptosis in LNCaP cells. Midkine activated extracellular signalregulated kinase I/2 and p38 mitogen-activated protein kinase pathways in LNCaP cells. Furthermore, midkine expression was significantly increased in late stage prostate cancer, which coincides with previously reported high serum levels of TNF $\alpha$ in advanced prostate cancer.
\end{abstract}

Conclusion: These findings provide the first demonstration that midkine expression is induced by certain growth factors and cytokines, particularly TNF $\alpha$, which offers new insight into understanding how midkine expression is increased in the late stage prostate cancer. 


\section{Background}

Midkine (MDK, or $\mathrm{MK}$ ) is a $13-\mathrm{kDa}$ heparin-binding growth factor originally identified by screening of retinoic acid-responsive genes $[1,2]$. MDK plays important roles in the nervous system, inflammation, and cancer [3-5]. MDK has been shown to induce transformation of NIH3T3 cells and to promote cell growth, survival, and migration, as well as angiogenesis [6-10]. Therefore, it is not surprising that MDK has been found to be over-expressed in various human cancers, including esophageal, gastric, colon, pancreatic, hepatocellular, lung, breast, and urinary bladder carcinomas, neuroblastomas, and Wilms' tumors $[11,12]$.

Prostate cancer is the most common malignant disease and the second most common cause of cancer-related death in American men [13]. The patients succumb to androgen-independent cancers that demonstrate alterations in androgen receptor signaling, apoptosis, and neuroendocrine differentiation. Konishi and coworkers first reported that MDK expression was positive in $86.3 \%$ of clinical prostate cancer, while normal prostate tissues were negative or showed only weak staining by immunohistochemical staining [14]. They also found that metastatic lesions generally showed higher MDK expression than the corresponding primary tumors. This was supported by a recent report that MDK expression was higher in C4-2 cells (androgen-independent derivative of LNCaP cells, with high tumorigenic and metastatic potential) than in LNCaP cells [15]. However, the biological role of MDK in prostate cancer has not been well addressed.

In this study, we found that fetal bovine serum (FBS) significantly induced MDK expression in LNCaP cells. As the results of searching for the serum factors that induced $\mathrm{MDK}$ expression, we identified TNF $\alpha$ as the strongest inducer of MDK expression in LNCaP cells. Further investigation revealed that MDK supported LNCaP cell survival.

\section{Methods \\ Cell culture}

Human prostate cancer cell line LNCaP and PC3 cells were from the American Type Culture Collection (Manassas, VA). LNCaP cells were routinely maintained in Tmedium (custom formula \# 02-0056) with 5\% FBS (Invitrogen, Carlsbad, CA). PC3 cells were maintained in Ham's F12K medium with 10\% FBS. The cells were cultured in a $37^{\circ} \mathrm{C}, 5 \% \mathrm{CO}_{2}$ humidified incubator. To avoid any interference from the insulin and triiodothyronine (T3) in the T-medium, the culture medium was switched to serum-free Dulbecco's Modified Eagles Medium (DMEM, Invitrogen, Carlsbad, CA) $16 \mathrm{~h}$ after plating the cells for all the experiments in this study. Each experiment was repeated at least twice and only reproducible data were presented in this report.

\section{Analysis of MDK protein expression by Western blot analysis}

500,000 LNCaP cells in one ml 5\% FBS T-medium per well were plated in 12-well plates and $16 \mathrm{~h}$ later changed into serum-free DMEM with or without growth factors and cytokines. There was no additional treatment during the following $48 \mathrm{~h}$. Control: serum-free DMEM $+1 \mu \mathrm{l}$ phosphate buffered saline (solvent for growth factors and cytokines) $+1 \mu$ l ethanol (solvent for DHT and R1881); the concentrations of growth factors and cytokines were: $10 \mathrm{ng} / \mathrm{ml}$ recombinant human insulin, $10 \mathrm{ng} / \mathrm{ml}$ recombinant human IGF-I, $10 \mathrm{ng} / \mathrm{ml}$ recombinant human EGF, $10 \mathrm{ng} / \mathrm{ml}$ recombinant human $\mathrm{HGF}, 10 \mathrm{ng} / \mathrm{ml}$ recombinant human bFGF, $20 \mathrm{ng} / \mathrm{ml}$ T3, $10 \mathrm{nM}$ DHT, $33.3 \mu \mathrm{M}$ all-trans-retinoic acid (RA) (Sigma-Aldrich, St. Louis, MO); $10 \mathrm{nM}$ R1881 (synthetic androgen, Perkin-Elmer, Boston, MA); $10 \mathrm{ng} / \mathrm{ml} \mathrm{TNF} \alpha, 10 \mathrm{ng} / \mathrm{ml} \mathrm{IL-} 1 \beta, 50 \mathrm{ng} / \mathrm{ml}$ IL-6, and $50 \mathrm{ng} / \mathrm{ml}$ IL-17 (R\&D Systems Inc., Minneapolis, $\mathrm{MN}) .48 \mathrm{~h}$ after treatment, the culture medium was collected and centrifuged at $20,800 \times \mathrm{g}$ for $5 \mathrm{~min}$ at $4{ }^{\circ} \mathrm{C}$. LNCaP cells were also treated with different dosages ( 1 to $50 \mathrm{ng} / \mathrm{ml}$ ) of TNF $\alpha$ for $48 \mathrm{~h}$, or $20 \mathrm{ng} / \mathrm{ml} \mathrm{TNF} \alpha$ for different time periods ( 8 to $48 \mathrm{~h}$ ). PC3 cells were also treated with or without $20 \mathrm{ng} / \mathrm{ml} \mathrm{TNF} \alpha$ in serum-free medium for $48 \mathrm{~h}$. For Western blot analysis, $20 \mu \mathrm{l}$ of each medium supernatant was subjected to $12 \%$ SDS-polyacrylamide gel electrophoresis and transferred to polyvinylidene difluoride membrane by electroblotting. The membranes were blocked with $5 \%$ nonfat dry milk in TBST $(25 \mathrm{mM}$ Tris-HCl, $125 \mathrm{mM} \mathrm{NaCl}, 0.1 \%$ Tween 20) for 2 hours and probed with rabbit anti-MDK antibodies (PeproTech, Inc., Rocky Hill, NJ) overnight and then horseradish peroxidase-conjungated secondary antibodies for 1 hour. The results were visualized by enhanced chemiluminescence (SuperSignal West Pico Chemiluminescent Substrate, Pierce Biotechnology, Inc., Rockford, IL) according to the manufacturer's instructions. For densitometry, the integrated density values (IDV) of the protein bands were analyzed by FluorChem IS-5500 (Alpha Innotech) and normalized to the control group (arbitrarily assigned a value of 1 ).

\section{Analysis of MDK mRNA expression by real-time quantitative RT-PCR}

Total RNA was extracted from LNCaP cells not treated or treated with $20 \mathrm{ng} / \mathrm{ml} \mathrm{TNF} \alpha$, using RNeasy Mini Kit (QIAGEN, Valencia, CA) with on-membrane DNase I digestion to avoid genomic DNA contamination. cDNA was made from total RNA using Superscript ${ }^{\mathrm{TM}}$ First-Strand Synthesis System with oligo dT primers (Invitrogen, Carlsbad, CA). Human MDK and glyceraldehyde-3-phosphate dehydrogenase (GAPDH) primers were obtained from Applied Biosystems (Foster City, CA). Real-time quantitative PCR was done in triplicates with an ABI 7700 Sequence Detector and Sybr-Green reagents (Applied Biosystems) follow- 
ing the recommended protocols [16]. Results were normalized to GAPDH levels using the formula $\Delta \mathrm{Ct}$ (Cycle threshold) $=$ Ct of MDK - Ct of GAPDH. Since LNCaP cells without treatment for $8 \mathrm{~h}$ expressed the lowest levels (but detectable, $\mathrm{Ct}=18.3 \sim 19.0$ ) of $\mathrm{MDK}, \Delta \Delta \mathrm{Ct}$ was calculated using the formula $\Delta \Delta \mathrm{Ct}=\Delta \mathrm{Ct}$ of any group - $\Delta$ Ct of LNCaP cells without treatment for $8 \mathrm{~h}$. The data were presented as fold change of MDK mRNA compared to LNCaP cells without treatment for $8 \mathrm{~h}$, where fold = $2^{\Delta \Delta \mathrm{Ct}}$.

\section{Inhibition of MDK expression by nuclear factor- $K B$ (NF- $\kappa B)$ inhibitor}

LNCaP cells were plated as described previously. They were not treated or treated for $48 \mathrm{~h}$ with increasing dosages (from 1 to $20 \mathrm{ng} / \mathrm{ml}$ ) of TNF $\alpha$ plus constant dosage $(18 \mu \mathrm{M})$ of a NF- $\kappa B$ inhibitor (Santa Cruz Biotechnology, Inc., Santa Cruz, CA). Alternatively, they were treated for $48 \mathrm{~h}$ with constant dosage $(20 \mathrm{ng} / \mathrm{ml})$ of TNF $\alpha$ plus increasing dosages (from 2.25 to $18 \mu \mathrm{M}$ ) of NF-kB inhibitor. The medium supernatants were analyzed for MDK protein expression by Western blot analysis as described above.

\section{Cell viability}

20,000 LNCaP cells in one ml 5\% FBS T-medium per well in triplicate groups were plated in 12-well plates and $16 \mathrm{~h}$ later changed into serum-free DMEM with or without 20 $\mathrm{ng} / \mathrm{ml} \mathrm{TNF} \alpha$. To test the effect of exogenous MDK on cell survival, 0.1 or $1 \mu \mathrm{g} / \mathrm{ml}$ of recombinant human MDK (PeproTech, Inc., Rocky Hill, NJ) were added $30 \mathrm{~min}$ before adding TNF $\alpha$. Two or four days after treatment, cell viability was determined by the trypan blue exclusion assay, in which cell survival was calculated as (the living cell number of treated group $\div$ the living cell number of untreated control group) $\times 100$. Based on our previous experience [17], we chose to determine the cell survival after four-day treatment to better evaluate the protective effects of MDK (Figure 1A), while after two-day treatment to show the combined killing effects of siRNA with TNFa (Figure 1C).

\section{Knockdown of endogenous MDK expression by small interfering RNA (siRNA)}

20,000 LNCaP cells in one ml 5\% FBS T-medium per well were plated in 12-well plates and $16 \mathrm{~h}$ later transfected with the mixtures of siRNA/Lipofectamine ${ }^{\mathrm{TM}} 2000$ (Invitrogen, Carlsbad, CA), control-siRNA/Lipofectamine ${ }^{\mathrm{TM}}$ 2000, or Lipofectamine ${ }^{\mathrm{TM}} 2000$ only (mock transfection), or no transfection as an additional control, according to the manufacturer's protocol [17]. The siRNA was the ONTARGETplus SMARTpool pre-designed siRNA targeting human MDK (catalog \# L-003677-00, Dharmacon, Inc., Lafayette, CO). The control-siRNA was a scrambled Stealth $^{\mathrm{TM}}$ siRNA negative control (Invitrogen, Carlsbad,
$\mathrm{CA}$ ). The final concentrations used were $100 \mathrm{nM}$ of siRNA or control-siRNA, and $5 \mu \mathrm{l} / \mathrm{ml}$ of Lipofectamine ${ }^{\mathrm{TM}} 2000$. Four $\mathrm{h}$ after transfection, the cells were changed into serum-free DMEM without or with $20 \mathrm{ng} / \mathrm{ml}$ TNFa. Two days later, the medium supernatants were analyzed for MDK protein expression by Western blot analysis and the cell viability was determined by the trypan blue exclusion assay as described above. To confirm that the LNCaP cells died through the caspase-3-mediated apoptosis as we observed previously [17], the Caspase 3\&7 Magic Red Kit (Immunochemistry Technologies, LLC., Bloomington, MN) was used to detect activated caspase-3. Briefly, a fluorophore (cresyl violet) was coupled to the four amino acid peptides (DEVD, optimal substrate of active caspase$3 \& 7$ ) and not able to fluoresce. When active caspase-3 or 7 cleaved off DEVD, cresyl violet emitted red fluorescence. Sixteen $\mathrm{h}$ after the siRNA transfection and TNFa treatment, $20 \mu \mathrm{M}$ MR-(DEVD) $)_{2}$ were added to the cells and incubated for $1 \mathrm{~h}$, followed by addition of $1 \mu \mathrm{g} / \mathrm{ml}$ Hoechst 33342 for another $15 \mathrm{~min}$. The red fluorescence (indicating activation of caspase-3) and blue fluorescent nuclei (stained by Hoechst 33342 to illustrate total cell number) were captured by a fluorescent microscope.

\section{Activation of intracellular signaling pathways by exogenous MDK}

Three million LNCaP cells in $10 \mathrm{ml}$ 5\% FBS T-medium per dish were plated in 100-mm dishes and $16 \mathrm{~h}$ later changed into serum-free DMEM for another $16 \mathrm{~h}$. Then, $100 \mathrm{ng} / \mathrm{ml}$ recombinant human MDK was added to the cells for 5 to $480 \mathrm{~min}$. The cells were harvested for protein isolation and Western blot analysis as described previously $[16,17]$. The antibodies used were: pERK1/2 (pERK, Santa Cruz Biotechnology, Santa Cruz, CA), ERK1/2, P-p38, p38, PAkt (serine 473), and Akt (Cell Signaling Technology, Beverly, MA). For loading control, the membranes were stripped and probed for GAPDH (antibodies from Chemicon, Temecula, CA). For densitometry, the IDVs of the protein bands were analyzed by FluorChem IS-5500 (Alpha Innotech) and normalized to the control group (arbitrarily assigned a value of 1 ).

\section{Immunohistochemical staining}

Prostate tissue microarray slides were prepared at the New York University Medical Center and consisted of a total of 132 cases. Each case was represented by two $0.6-\mathrm{mm}$ tissue cores. Among them, 129 cases ( 18 normal prostate tissues, 40 early stage cancers, and 71 late stage cancers) were analyzed (3 cases lost both tissue cores). The early stage cancer specimens were from radical prostatectomy specimens derived from patients with clinically localized prostate cancer. Half of this group of patients had previously undergone neoadjuvant therapy for 3 months prior to radical prostatectomy. The late stage cancer specimens were from transurethral resection of hormone naïve or 

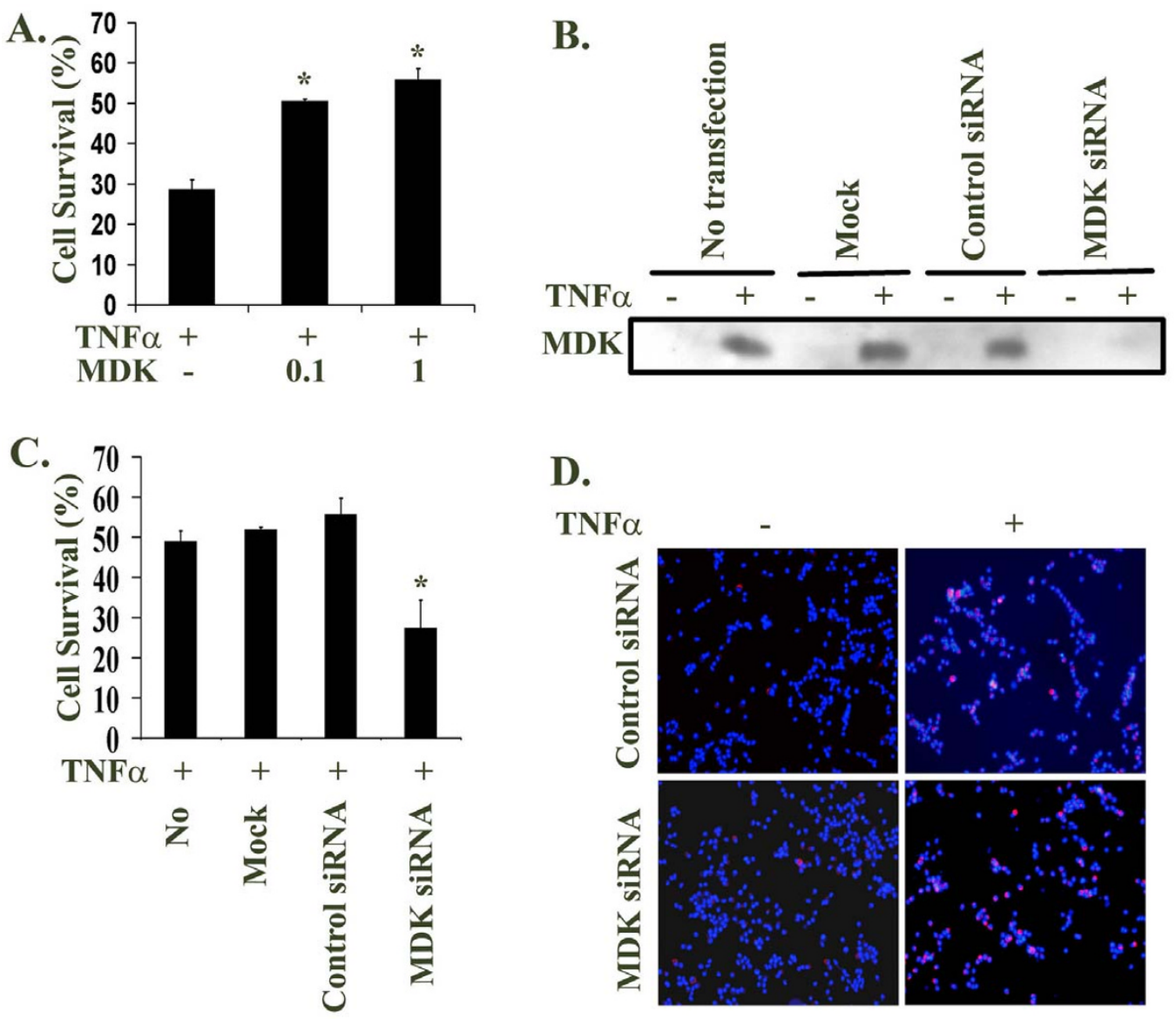

\section{Figure I}

Midkine partially inhibited TNF $\alpha$-induced apoptosis in LNCaP cells. A. LNCaP cells in triplicate groups were not treated (as control) or treated for 4 days with $20 \mathrm{ng} / \mathrm{ml} \mathrm{TNF} \alpha$, without or with 0.1 or I $\mu \mathrm{g} / \mathrm{ml}$ exogenous midkine; the living cell number was counted by the trypan blue exclusion assay; the cell survival was calculated as (the living cell number of treated group $\div$ the living cell number of untreated control group); the data were presented as mean \pm standard deviation; $* \mathrm{P}<0.05$ compared to TNF $\alpha$ alone. B. LNCaP cells were transfected with the mixtures of midkine specific siRNA/Lipofectamine ${ }^{\mathrm{TM}} 2000$, controlsiRNA/Lipofectamine ${ }^{\text {TM }} 2000$, or Lipofectamine ${ }^{\text {TM }} 2000$ only (mock transfection), or no transfection as an additional control; the final concentrations used were $100 \mathrm{nM}$ of siRNA or control-siRNA, and $5 \mu \mathrm{l} / \mathrm{ml}$ of Lipofectamine ${ }^{\mathrm{TM}} 2000$; four $\mathrm{h}$ after transfection, the cells were changed into serum-free DMEM without or with $20 \mathrm{ng} / \mathrm{ml} \mathrm{TNF} \alpha$; two days later, the medium supernatants were analyzed for midkine expression by Western blot. $\mathbf{C}$. LNCaP cells in triplicate groups were treated as described in B; the cell survival after 2-days' treatment with $20 \mathrm{ng} / \mathrm{ml}$ TNF $\alpha$ was determined by the trypan blue exclusion assay as described in $\mathbf{A}$; the data were presented as mean \pm standard deviation; ${ }^{*} \mathrm{P}<0.05$ compared to the other three groups. $\mathbf{D}$. LNCaP cells were treated as described in B; $16 \mathrm{~h}$ after treatment with $20 \mathrm{ng} / \mathrm{ml}$ TNF $\alpha, 20 \mu M$ MR-(DEVD) 2 were added to the cells and incubated for I $\mathrm{h}$, followed by addition of I $\mu \mathrm{g} / \mathrm{ml}$ Hoechst 33342 for another $\mathrm{I} 5 \mathrm{~min}$; the red fluorescence [emitted by the cleaved MR-(DEVD) 2 indicating activation of caspase-3] and blue fluorescent nuclei (stained by Hoechst 33342 to illustrate total cell number) were captured by a fluorescent microscope; original magnification: $\times 100$.

resistant prostate cancer that had advanced beyond the stage treatable by radical prostatectomy. Non-tumorous prostate tissues were also derived from the radical prostatectomy specimens. The collection of the specimens was approved by the New York University Institution Review Board.
The prostate tissue microarray slides were stained with 0.6 $\mu \mathrm{g} / \mathrm{ml}$ rabbit anti-MDK antibodies using the VECTSTAIN elite ABC Reagent and DAB Substrate Kit (Vector Laboratories, Burlingame, $\mathrm{CA}$ ) according to the manufacturer's protocol $[16,18]$. The stained slides were assessed independently by two pathologists (X.K. and J.M.) and a consensus of grading was reached. The evaluation criteria of Konishi et al were adopted, i.e., samples were considered 
negative (-) if less than $20 \%$ of epithelial cells were stained for MDK, weakly positive (+) if $20-50 \%$ of epithelial cells were stained, and strongly positive (++) if more than $50 \%$ of epithelial cells were stained [14].

\section{Statistical analysis}

The Student's $t$-test was used to analyze the MDK mRNA expression data and the cell survival data. The difference of Gleason scores between the early stage and late stage cancers was analyzed by the Mann-Whitney U test. The immunohistochemical staining data were analyzed by the Kruskal-Wallis test. $\mathrm{P}<0.05$ was considered statistically significant.

\section{Results \\ Induction of MDK protein expression by growth factors and cytokines}

In this study, we found that FBS induced MDK expression in the human prostate cancer LNCaP cells (Figure 2A). To rule out the possibility that the FBS contained MDK, we loaded the same amount of FBS as in the 10\% FBS medium and did not detect any MDK signal (data not shown). This suggested that it was serum factors in the FBS that induced MDK expression in LNCaP cells. Therefore, we tested a panel of thirteen growth factors and cytokines including RA for their effects on MDK induction. Unlike in the teratocarcinoma stem cells, RA did not induce MDK expression in LNCaP cells. Insulin, recombinant human basic fibroblast growth factor (bFGF), triiodothyronine (T3), interleukin-6 (IL-6) and interleukin-17 (IL-17) did not stimulate MDK expression, either (Figure 2A). Recombinant human insulin-like growth factor-I (IGF-I) and hepatocyte growth factor (HGF) slightly induced MDK expression, while epidermal growth factor (EGF), dihydrotestosterone (DHT), R1881 (synthetic androgen), and interleukin-1 $\beta$ (IL-1 $\beta$ ) modestly stimulated MDK expression (Figure 2A). However, TNFa induced a dramatic increase in MDK expression and was the strongest inducer among the agents tested (Figure 2A).

\section{TNF $\alpha$ induced MDK expression through NF- $\kappa B$ pathway}

Since TNF $\alpha$ was the strongest inducer of MDK expression in LNCaP cells, we further characterized the induction of MDK expression by TNF $\alpha$. We found that as low as $1 \mathrm{ng} /$ $\mathrm{ml}$ of TNF $\alpha$ slightly induced MDK protein expression and the induction was dose-dependent over a range up to 50 $\mathrm{ng} / \mathrm{ml}$ (Figure 2B). Furthermore, MDK protein was detected in the cell culture medium after $24 \mathrm{~h}$ treatment with $20 \mathrm{ng} / \mathrm{ml}$ of TNF $\alpha$, but not in the untreated control medium at this point (Figure 2C). To determine if the induction of MDK expression was at mRNA level, we did real-time quantitative RT-PCR analysis of MDK mRNA expression. We found that MDK mRNA expression was significantly induced by TNF $\alpha$ after $24 \mathrm{~h}$ treatment and continued to increase up to $48 \mathrm{~h}$ (Figure 2D). MDK mRNA

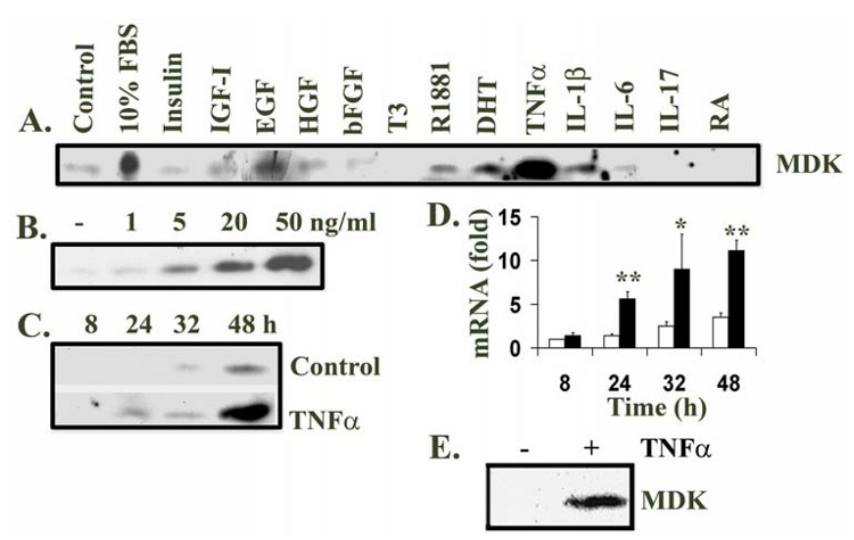

Figure 2

Midkine expression was induced by FBS, growth factors and cytokines. A. LNCaP cells were cultured in serum-free DMEM and treated for $48 \mathrm{~h}$ with $10 \% \mathrm{FBS}$ and the indicated agents: $10 \mathrm{ng} / \mathrm{ml}$ insulin, $10 \mathrm{ng} / \mathrm{ml}$ IGF-I, $10 \mathrm{ng} / \mathrm{ml}$ EGF, $10 \mathrm{ng} /$ $\mathrm{ml} \mathrm{HGF,} 10 \mathrm{ng} / \mathrm{ml}$ bFGF, $20 \mathrm{ng} / \mathrm{ml} \mathrm{T3}, 10 \mathrm{nM}$ R/88I, $10 \mathrm{nM}$ DHT, $10 \mathrm{ng} / \mathrm{ml}$ TNF $\alpha, 10 \mathrm{ng} / \mathrm{ml} \mathrm{IL-I} \beta, 50 \mathrm{ng} / \mathrm{ml} \mathrm{IL-6,50} \mathrm{ng/ml}$ IL-17, and 33.3 $\mu$ M RA. B. LNCaP cells were treated with different dosages (I to $50 \mathrm{ng} / \mathrm{ml}$ ) of TNF $\alpha$ for $48 \mathrm{~h}$. C. LNCaP cells were also treated with $20 \mathrm{ng} / \mathrm{ml}$ TNF $\alpha$ for different time periods ( 8 to $48 \mathrm{~h}$ ). $20 \mu \mathrm{l}$ of each medium supernatant was subjected to Western blot analysis of midkine expression using rabbit anti-midkine antibodies, horseradish peroxidaseconjungated secondary antibodies and enhanced chemiluminescence reagents. D. Total RNA was extracted from $\mathrm{LNCaP}$ cells not treated or treated with $20 \mathrm{ng} / \mathrm{ml} \mathrm{TNF} \alpha$, using RNeasy Mini Kit; cDNA was made from total RNA using Superscript ${ }^{\mathrm{TM}}$ First-Strand Synthesis System with oligo dT primers; real-time quantitative PCR was done in triplicates with Sybr-Green reagents; results were normalized to GAPDH levels as described in Methods; the data (mean \pm standard deviation of three independent experiments) were presented as fold change of midkine mRNA compared to the $\mathrm{LNCaP}$ cells without treatment for $8 \mathrm{~h}$, where fold $=2^{\Delta \Delta C t}$; solid bar, TNF $\alpha$ treated; open bar, control; $* \mathrm{P}<0.05$ and $* * \mathrm{P}<0.0 \mathrm{I}$, compared to the corresponding controls. E. PC3 cells were cultured in serum-free medium and treated for 48 h with or without $20 \mathrm{ng} / \mathrm{ml} \mathrm{TNF \alpha .} 20 \mu \mathrm{l}$ of each medium supernatant was subjected to Western blot analysis of midkine expression.

expression in the untreated cells also gradually and slightly increased over time (Figure 2D), which was consistent with the increase at protein level (Figure 2C). We also found that TNF $\alpha$ induced MDK protein expression in PC3 cells (Figure 2E) and LNCaP sublines C4-2, P151S, R248W and R273H cells [19] (data not shown).

Since TNF $\alpha$ induces expression of many genes through NF- $\mathrm{KB}$ pathway [20], we tested whether induction of MDK expression by TNF $\alpha$ was also mediated by NF- $\kappa B$ pathway. We utilized a synthetic cell-permeable peptide NF- $\kappa B$ inhibitor that inhibits nuclear translocation of NF- $\mathrm{B}$ 
active complex [21]. We found that $18 \mu \mathrm{M}$ NF- $\kappa \mathrm{B}$ inhibitor completely abolished $\mathrm{MDK}$ protein expression induced by $1 \mathrm{ng} / \mathrm{ml} \mathrm{TNF} \alpha$, while MDK expression induced by $5 \mathrm{ng} / \mathrm{ml}$ TNF $\alpha$ was inhibited to a level slightly below the basal level of the control (Figure 3A and 3B). However, at higher dosages of TNF $\alpha, \mathrm{MDK}$ expression was decreased compared to TNF $\alpha$-treated groups without the NF- $\kappa \mathrm{B}$ inhibitor, but its levels were above the basal level (Figure $3 \mathrm{~A}$ and $3 \mathrm{~B}$ ). In addition, inhibition of MDK induction by the NF- $\kappa \mathrm{B}$ inhibitor was in a dose-dependent manner (Figure 3C and 3D).

\section{MDK partially inhibited TNF $\alpha$-induced apoptosis in LNCaP cells}

Given that MDK was known to prevent apoptosis in other cell types [8,22], we tested whether exogenous MDK could inhibit TNFa-induced apoptosis in LNCaP cells. We found that about $28 \%$ of LNCaP cells were alive after being treated with $20 \mathrm{ng} / \mathrm{ml} \mathrm{TNF} \alpha$ for 4 days, but the cell survival rate was increased to $50 \%$ and $56 \%$ when 0.1 or $1 \mu \mathrm{g} / \mathrm{ml}$ recombinant human MDK was added (Figure $1 \mathrm{~A})$.

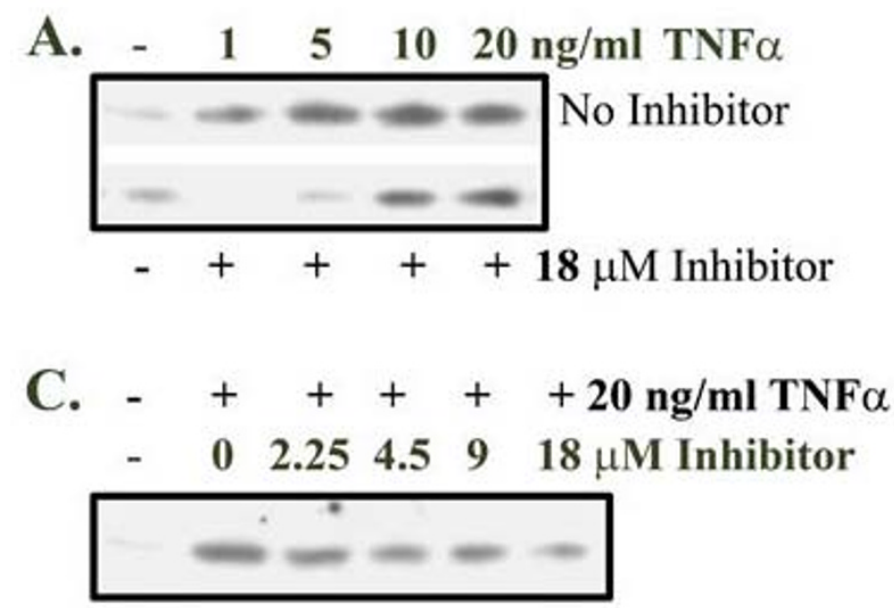

In addition, we used MDK-specific siRNA to knockdown the expression of endogenous MDK. As shown in Figure $1 \mathrm{~B}, \mathrm{TNF} \alpha$ induced endogenous MDK expression in the No transfection, Mock transfection, and Control-siRNA transfection groups, but not in the MDK-specific siRNA transfection group. Consequently, TNF $\alpha$-induced apoptosis in LNCaP cells was enhanced by knocking down endogenous MDK expression. As shown in Figure 1C, the cell survival rates in No transfection, Mock transfection, and Control-siRNA transfection groups were about 50\% after being treated by $20 \mathrm{ng} / \mathrm{ml}$ TNFa for 2 days, while the cell survival rate in MDK-specific siRNA transfection group was about $25 \%$. To confirm that the LNCaP cells died through caspase-3-mediated apoptosis as we observed previously [17], we used the Caspase $3 \& 7$ Magic Red Kit to detect activation of caspase-3. We found that the cells with active caspase- 3 were very rare in both ControlsiRNA and MDK-specific siRNA transfected groups without TNF $\alpha$ treatment. With TNF $\alpha$ treatment, the ControlsiRNA transfected group showed several cells with active caspase-3 (red fluorescence) per microscopic field, while the positive cell number was dramatically increased in the
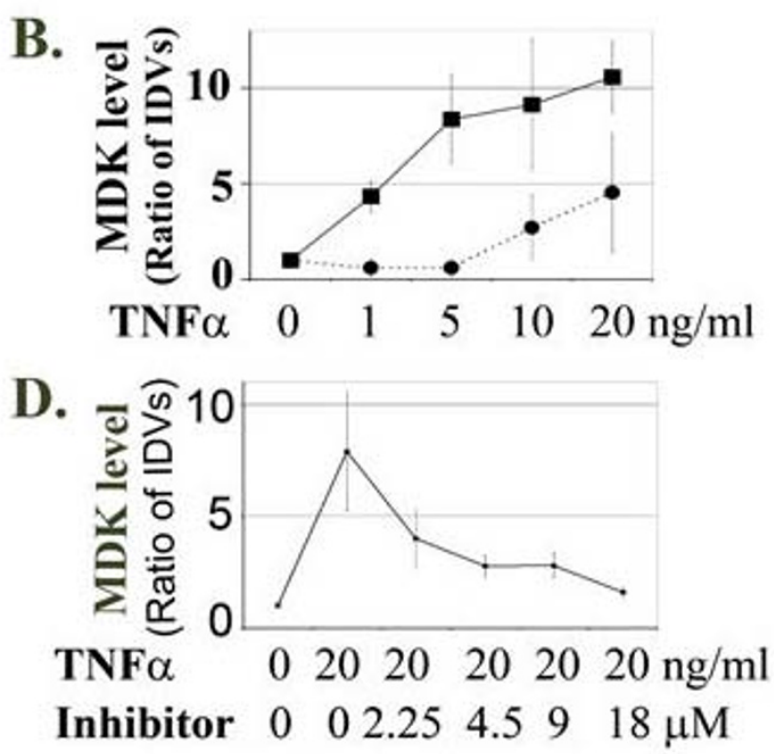

\section{Figure 3}

TNF $\alpha$ induced midkine expression through NF- $\kappa B$ pathway. A. LNCaP cells were not treated or treated for $48 \mathrm{~h}$ with increasing dosages of TNF $\alpha$, without (top blot) or with $18 \mu \mathrm{M}$ NF- $\kappa \mathrm{B}$ inhibitor (bottom blot); $20 \mu$ l of each medium supernatant was subjected to Western blot analysis of midkine expression. B. Densitometry of $\mathbf{A}$; the untreated control group was arbitrarily assigned a value of I; the integrated density values (IDVs) of the protein bands from other groups were divided by that of the control group (i.e., ratio of IDVs) to represent the relative MDK levels; solid line, TNF $\alpha$ only; dotted line, TNF $\alpha$ with I8 $\mu$ M NF- $\kappa B$ inhibitor. Data presented were average \pm standard deviations (error bars) of three independent experiments. C. LNCaP cells were not treated or treated for $48 \mathrm{~h}$ with $20 \mathrm{ng} / \mathrm{ml} \mathrm{TNF} \alpha$, and without or with increasing dosages of NF- $\kappa B$ inhibitor; $20 \mu$ of each medium supernatant was subjected to Western blot analysis of midkine expression. D. Densitometry of C as described in B. Data presented were average \pm standard deviations (error bars) of three independent experiments. 
MDK-specific siRNA transfected group (Figure 1D). Since we have determined previously that caspase-7 in LNCaP cells was not activated by TNF $\alpha$ [17], the detected signals were specific for caspase-3.

\section{MDK activated MAP kinase pathways}

As shown in Figure 4A and 4B, MDK induced phosphorylation of ERK1/2 starting 5 min after adding MDK, gradually increasing to a peak at $2 \mathrm{~h}$ and sustaining at a lower level thereafter for up to $8 \mathrm{~h}$. It is worth pointing out that the gradual decrease in unphosphorylated ERK1/2 was not caused by unequal loading, as the same samples loaded and probed for both GAPDH and unphosphorylated p38 showed almost equal signals over the time course (Figure 4A and 4B). Phosphorylation of p38 started after $1 \mathrm{~h}$ (Figure 4A and 4B). We found high basal levels of phosphorylated Akt and a slight increase in P-Akt and Akt after $1 \mathrm{~h}$ (Figure 4A and 4B).

\section{MDK expression was increased in late stage prostate cancer}

By immunohistochemical staining, we found that MDK expression was confined primarily to the cytoplasm of cancer cells and showed a diffuse staining pattern (Figure 5, Late Stage Cancer), which was consistent with the previous report [14]. As shown in Table 1, one out of the 18 normal prostate tissues showed weak staining for MDK, while the rest were negative. Three out of the 40 early stage prostate cancers were weakly positive, while 37 cases were negative. Of the 71 late stage prostate cancers, 6 cases were strongly positive, 24 cases were weakly positive, and 41 cases were negative. Analyzed by Kruskal-Wallis test, MDK expression was significantly higher in the late stage high grade prostate cancers than in the early stage intermediate grade prostate cancers or normal prostate tissues $(\mathrm{P}<$ 0.001 ), while no significant difference was found between the early stage prostate cancers and normal prostate tissues $(\mathrm{P}>0.05)$. It was noted that Gleason scores (indicating tumor differentiation) were significantly higher in the late stage prostate cancers than in the early stage prostate cancers $(\mathrm{P}<0.001)$.

\section{Discussion}

MDK has been shown to play an important role in development, cell survival, inflammation and tumorigenesis. In spite of its restricted expression in adult kidney, MDK expression is increased in disease conditions such as rheumatoid arthritis and cancer $[5,12,23]$. Intensive studies have been performed on how and what MDK can do in the various physiological and pathological processes. However, the upstream factors and signaling mechanisms that regulate MDK expression have not been identified. MDK was first identified as a retinoic acid-responsive gene in the teratocarcinoma stem cells [1]. Recently, MDK was found to be upregulated by hypoxia but downregulated
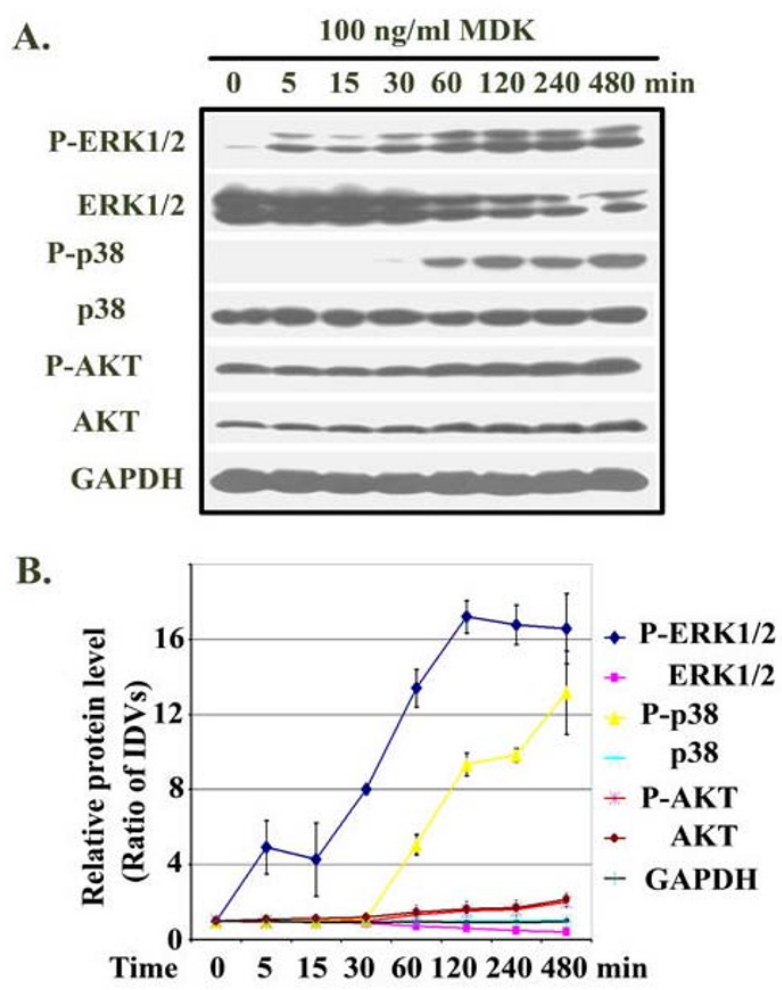

\section{Figure 4}

Midkine activated MAP kinase pathways in LNCaP cells. A. The serum-starved LNCaP cells were treated with $100 \mathrm{ng} / \mathrm{ml}$ recombinant human MDK for 5 to $480 \mathrm{~min}$; the cells were harvested for protein isolation and Western blot analysis of the indicated proteins; for loading control, the membranes were stripped and probed for GAPDH. B. Densitometry of $\mathbf{A}$; the untreated control group was arbitrarily assigned a value of I; IDVs of the protein bands from other groups were divided by that of the control group (i.e., ratio of IDVs) to represent the relative individual protein levels over the time course; of note, p38 and GAPDH lines overlapped. Data presented were average \pm standard deviations (error bars) of three independent experiments.

by cortisol [24,25]. Rebamipide, a mucoprotective drug used for the treatment of gastric ulcers, has been shown to upregulate MDK expression in rat gastric mucosal cells [26]. In this study, we found that fetal bovine serum stimulated MDK expression in a prostate cancer cell line LNCaP. Furthermore, we found that EGF, DHT, R1881, and IL-1 $\beta$ modestly stimulated MDK expression, while IGF-I and HGF slightly induced MDK expression. TNF $\alpha$ was identified as the strongest inducer of MDK expression in LNCaP cells, while insulin, bFGF, T3, IL-6, and IL-17 did not induce MDK expression in LNCaP cells. This, to our best knowledge, was the first time to identify these growth factors and cytokines as MDK inducers. It was reasonable to speculate that induction of MDK expression by 


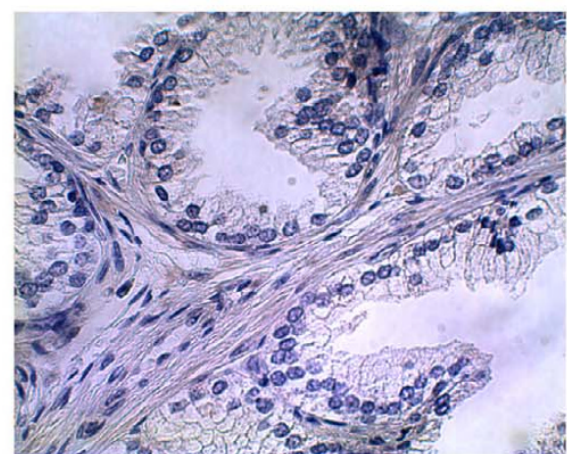

Normal Epithelium

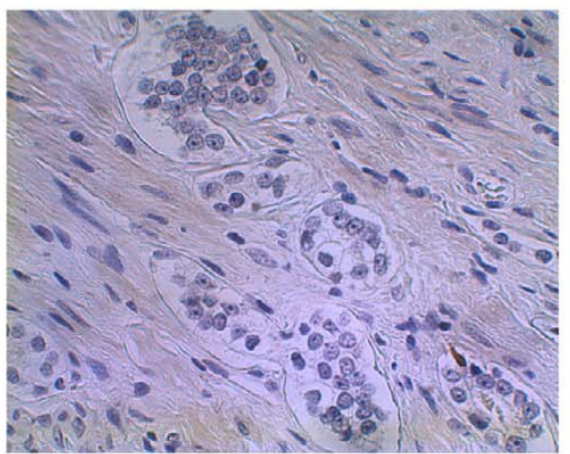

Early Stage Cancer

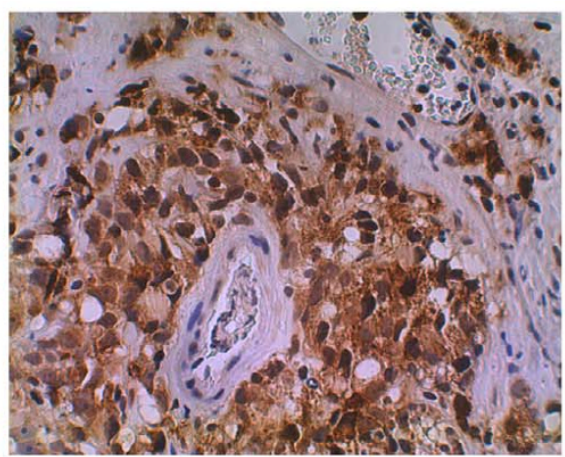

Late Stage Cancer

\section{Figure 5}

Immunohistochemical staining of prostate tissue microarrays. The early stage cancers were from radical prostatectomy specimens derived from patients with clinically localized prostate cancers; while the late stage cancers were derived from transurethral resection specimens of prostate cancers that had advanced beyond the stage treatable by radical prostatectomy; the normal prostate tissues were from the non-tumorous portions of the radical prostatectomy specimens; the prostate tissue microarray slides were stained with $0.6 \mu \mathrm{g} / \mathrm{ml}$ rabbit anti-midkine antibodies using the VECTSTAIN elite ABC Reagent and DAB Substrate Kit according to the manufacturer's protocol and counter-stained with hematoxylin; representative negative (Normal Epithelium and Early Stage Cancer) and strongly positive (Late Stage Cancer) midkine staining are shown; original magnification: $\times 400$.

fetal bovine serum might be a result of combined effects of low levels of TNF $\alpha$, EGF, DHT, IL-1 $\beta$, IGF-I, and HGF existing in the serum. Surprisingly, RA did not induce MDK expression in LNCaP cells, indicating a cell-specific effect of RA.

We found that TNF $\alpha$ induced MDK expression in a dosedependent and time-dependent manner at protein levels. At mRNA levels, TNF $\alpha$-induction of MDK expression was significant after $8 \mathrm{~h}$, indicating that MDK may belong to the late-response genes [27]. More importantly, induction

Table I: Midkine expression is increased in the late stage prostate cancers. Normal and prostate cancer tissue microarray slides were immunohistochemically stained for midkine, using rabbit anti-midkine antibodies and $A B C$ elite kit with DAB substrate, and counterstained by hematoxylin. The grading was assigned to each tissue core by a consensus review of two pathologists.

\begin{tabular}{lcccccccc}
\hline Tissue & No. & $\begin{array}{c}\text { Gleason score } \\
\text { median (range) }\end{array}$ & P & \multicolumn{3}{c}{ Midkine stain } & P \\
& & & + & & 17 & 1 & 0 & $\S$ \\
Normal & 18 & $6(5-7)$ & $*$ & 37 & 3 & 0 & $\dagger$ \\
Early stage cancer & 40 & $9(8-10)$ & & 41 & 24 & 6 & $\ddagger$ \\
Late stage cancer & 71 & & & & &
\end{tabular}

\footnotetext{
"-" indicates $\leq 20 \%$ of epithelial cells were immunopositive;

"+" indicates $20-50 \%$ of epithelial cells were immunopositive;

"++" indicates $\geq 50 \%$ of epithelial cells were immunopositive.

$* \mathrm{P}<0.001$, Gleason scores, early stage cancer v.s. late stage cancer. $\S P>0.05$, normal v.s. early stage cancer.

$+P<0.001$, early stage cancer v.s. late stage cancer

$\ddagger \mathrm{P}<0.001$, normal v.s. late stage cancer.
}

of MDK expression by TNF $\alpha$ was through NF- $\kappa B$ pathway, as NF- $\kappa \mathrm{B}$ inhibitor could dose-dependently inhibit TNF $\alpha$ induced MDK expression. Uehara and co-workers have previously predicted a putative NF- $\kappa \mathrm{B}$-binding site in the 5 ' non-coding region of MDK gene [28]. In this study, we provided the first direct evidence that MDK was a NF- $\mathrm{B}$ inducible gene.

MDK has previously been shown to prevent apoptosis in other cell types $[8,22]$. In this study, we found that exogenously added recombinant human MDK partially inhibited TNF $\alpha$-induced apoptosis in LNCaP cells. Knocking down the endogenous MDK expression by siRNA enhanced TNF $\alpha$-induced apoptosis through activation of caspase- 3 in LNCaP cells. These data suggested that MDK supported LNCaP cell survival, although its strength was not sufficient to prevent the eventual cell death in this in vitro cell model. Our study showed that MDK also activated ERK1/2 pathway as early as within 5 minutes of treatment in LNCaP cells. Activation of PI3k/Akt pathway by MDK was less obvious in LNCaP cells, due to the constitutively high basal level of activity [29]. Furthermore, we found p38 pathway was dramatically activated by MDK after one hour treatment, while c-jun NH2 terminal kinase pathway was not activated (data not shown). Activation of the ERK1/2 pathway has been reported to primarily results in cell survival, while the role of p38 pathway is less clear, although recent studies indicate a role in cell survival in certain cell types [30-32]. The ERK1/2 pathway has been shown to induce BAD phosphorylation at $\operatorname{Ser}^{112}$ and thereby protect LNCaP cells from apoptosis [33,34]. 
In previous studies, MDK has been shown to inhibit apoptosis through activation of ERK1/2 and PI3k/Akt pathways in neurons and cardiomyocytes $[8,22,35]$. It remains to be tested if the same mechanism is true in prostate cancer cells.

MDK has been found to be over-expressed in various human cancers, including esophageal, gastric, colon, pancreatic, hepatocellular, lung, breast, and urinary bladder carcinomas, as well as neuroblastomas and Wilms' tumors $[11,12]$. MDK expression in prostate cancer tissues was reported by one group [14]. In this study, we found that the normal prostate tissues and early stage intermediate grade prostate cancers are negative or only weakly positive for MDK expression, while MDK expression is significantly increased in the late stage prostate cancers with higher Gleason scores. Konishi and co-workers have previously reported that there appears to be a significant positive correlation of MDK immunoreactivity and higher Gleason scores [14]. However, it was noteworthy that only $42 \%$ of the late stage cancers and $8 \%$ of the early stage cancers were positive for MDK staining in the current study, while $79 \%$ of the biopsied cancers (including $89 \%$ of cancers with Gleason's pattern $\geq 4$ and $68 \%$ of cancers with Gleason's pattern $\leq 3$ ) were positive in the previous study [14]. This disparity may be due to using different antibodies and staining protocols, or different sampling. Nevertheless, Michalaki and co-workers reported that the serum levels of TNF $\alpha$ in patients with locally advanced/ metastatic prostate cancers were about 4 to 6 times of those in normal men, while the serum levels of TNF $\alpha$ in patients with localized prostate cancers were only 1.3 times of those in normal men [36]. Therefore, it is possible that increased MDK expression the in late stage prostate cancers may be induced by increased systemic and/or local TNF $\alpha$ and other factors as identified in this study.

What remains not clear is that TNFa eventually kills $\mathrm{LNCaP}$ cells in vitro, but the in vivo tumors continue to grow in the presence of high TNF $\alpha$. One possibility is that the TNFa dosage used in our study is significantly higher than the in vivo concentration of TNF $\alpha$. It has been reported that the normal physiological serum levels of TNF $\alpha$ vary from 1 to $13 \mathrm{pg} / \mathrm{ml}$ [36-39]. Under pathological conditions, serum TNFa levels can be as high as $53 \mathrm{pg} /$ $\mathrm{ml}$ in advanced stage of cancer [39], or even $368 \mathrm{pg} / \mathrm{ml}$ in rheumatoid arthritis patients [37]. The local tissue TNF $\alpha$ levels may be higher than the serum levels as serum TNF $\alpha$ has a very short half-life $[40,41]$. It may also be possible that TNF $\alpha$ induces not only MDK expression, but also expression of other anti-apoptotic genes in vivo. MDK may promote angiogenesis in vivo and therefore provide further support for tumor growth [42]. Combination of MDK specific siRNA and chemotherapy may be a promis- ing strategy for the late stage prostate cancers as shown by a recent study [43].

\section{Conclusion}

This study provides the first demonstration that midkine expression is induced by certain growth factors and cytokines, particularly $\mathrm{TNF} \alpha$, which offers new insight into understanding how midkine expression is increased in the late stage prostate cancers. Given the anti-apoptotic role of MDK in prostate cancer cells, our findings further support the new strategy to target MDK using specific siRNA as shown by a recent study [43].

\section{Abbreviations}

bFGF, basic fibroblast growth factor; $\mathrm{Ct}$, cycle threshold; DMEM, Dulbecco's Modified Eagles Medium; DHT, dihydrotestosterone; EGF, epidermal growth factor; ERK, extracellular signal-regulated kinase; FBS, fetal bovine serum; GAPDH, glyceraldehyde-3-phosphate dehydrogenase; HGF, hepatocyte growth factor; IDV, integrated density values; IGF-I, insulin-like growth factor-I; IL-1 $\beta$, interleukin-1 beta; IL-6, interleukin-6; IL-17, interleukin17; IL-17RL, interleukin-17 receptor-like; MAP, mitogenactivated protein; $\mathrm{MDK}$ or $\mathrm{MK}$, midkine; $\mathrm{NF}-\kappa \mathrm{B}$, nuclear factor-kappa B; PI3K, phosphatidyl-inositol 3-kinase; RA, retinoic acid; RT-PCR, reverse transcription-polymerase chain reaction; siRNA, small interfering RNA; T3, triiodothyronine; TNF, tumor necrosis factor.

\section{Competing interests}

The author(s) declare that they have no competing interests.

\section{Authors' contributions}

ZY conceived and designed the study, performed the in vitro experiments, and drafted the manuscript. YD and RGE did immunohistochemical staining. XK and JM provided the prostate tissue microarray slides and evaluated the stained slides. LAB contributed to the design and statistical analysis. All authors were involved in preparing the manuscript.

\section{Acknowledgements}

We thank Dr. A Hari Reddi (University of California Davis) for helpful suggestions and critical reading of the manuscript, Dr. Ralph W. de Vere White (University of California Davis) for insightful discussions, and Judy Li (Statistician, University of California Davis) for help on statistics. This work was supported in part by a grant from U.S. Army Medical Research and Material Command, Department of Defense, W8IXWH-05-I-0567 (to ZY) and the University of California Davis Cancer Center CCSG Biostatistics Shared Resource

\section{References}

I. Kadomatsu K, Tomomura M, Muramatsu T: cDNA cloning and sequencing of a new gene intensely expressed in early differentiation stages of embryonal carcinoma cells and in midgestation period of mouse embryogenesis. Biochem Biophys Res Commun 1988, 151(3): $1312-1318$. 
2. Tomomura M, Kadomatsu K, Matsubara S, Muramatsu T: A retinoic acid-responsive gene, MK, found in the teratocarcinoma system. Heterogeneity of the transcript and the nature of the translation product. J Biol Chem 1990, 265( ( 8): 10765-10770.

3. Nakamura E, Kadomatsu K, Yuasa S, Muramatsu H, Mamiya T, Nabeshima T, Fan QW, Ishiguro K, Igakura T, Matsubara S, Kaname T, Horiba M, Saito H, Muramatsu T: Disruption of the midkine gene (Mdk) resulted in altered expression of a calcium binding protein in the hippocampus of infant mice and their abnormal behaviour. Genes Cells 1998, 3(I 2):8I I-822.

4. Zou P, Muramatsu H, Sone M, Hayashi H, Nakashima T, Muramatsu $\mathrm{T}$ : Mice doubly deficient in the midkine and pleiotrophin genes exhibit deficits in the expression of beta-tectorin gene and in auditory response. Lab lnvest 2006.

5. Maruyama K, Muramatsu H, Ishiguro N, Muramatsu T: Midkine, a heparin-binding growth factor, is fundamentally involved in the pathogenesis of rheumatoid arthritis. Arthritis Rheum 2004 50(5): $1420-1429$

6. Kadomatsu K, Hagihara M, Akhter S, Fan QW, Muramatsu H, Muramatsu T: Midkine induces the transformation of NIH3T3 cells. Br J Cancer 1997, 75(3):354-359.

7. Muramatsu H, Shirahama H, Yonezawa S, Maruta H, Muramatsu T: Midkine, a retinoic acid-inducible growth/differentiation factor: immunochemical evidence for the function and distribution. Dev Biol 1993, 159(2):392-402.

8. Owada K, Sanjo N, Kobayashi T, Mizusawa H, Muramatsu H, Muramatsu T, Michikawa M: Midkine inhibits caspase-dependent apoptosis via the activation of mitogen-activated protein kinase and phosphatidylinositol 3-kinase in cultured neurons. J Neurochem 1999, 73(5):2084-2092.

9. Qi M, Ikematsu S, Maeda N, Ichihara-Tanaka K, Sakuma S, Noda M, Muramatsu T, Kadomatsu K: Haptotactic migration induced by midkine. Involvement of protein-tyrosine phosphatase zeta Mitogen-activated protein kinase, and phosphatidylinositol 3-kinase. J Biol Chem 200I, 276(19): I 5868-I5875.

10. Choudhuri R, Zhang HT, Donnini S, Ziche M, Bicknell R: An angiogenic role for the neurokines midkine and pleiotrophin in tumorigenesis. Cancer Res 1997, 57(9):1814-1819.

II. Tsutsui J, Kadomatsu K, Matsubara S, Nakagawara A, Hamanoue M, Takao S, Shimazu H, Ohi Y, Muramatsu T: A new family of heparin-binding growth/differentiation factors: increased midkine expression in Wilms' tumor and other human carcinomas. Cancer Res 1993, 53(6): | 28|-| 285.

12. Kadomatsu K, Muramatsu T: Midkine and pleiotrophin in neural development and cancer. Cancer Lett 2004, 204(2): 127-|143.

13. Jemal A, Siegel R, Ward E, Murray T, Xu J, Thun MJ: Cancer Statistics, 2007. CA Cancer J Clin 2007, 57(I):43-66.

14. Konishi N, Nakamura M, Nakaoka S, Hiasa Y, Cho M, Uemura $H$ Hirao Y, Muramatsu T, Kadomatsu K: Immunohistochemical analysis of midkine expression in human prostate carcinoma. Oncology 1999, 57(3):253-257.

15. Trojan L, Schaaf A, Steidler A, Haak M, Thalmann G, Knoll T, Gretz $\mathrm{N}$, Alken P, Michel MS: Identification of metastasis-associated genes in prostate cancer by genetic profiling of human prostate cancer cell lines. Anticancer Res 2005, 25(IA): I83-191.

16. You Z, DuRaine G, Tien JY, Lee C, Moseley TA, Reddi AH: Expression of interleukin- I7B in mouse embryonic limb buds and regulation by BMP-7 and bFGF. Biochem Biophys Res Commun 2005, 326(3):624-631.

17. You Z, Shi XB, DuRaine G, Haudenschild D, Tepper CG, Lo SH, Gandour-Edwards R, de Vere White RW, Reddi AH: Interleukin-17 receptor-like gene is a novel antiapoptotic gene highly expressed in androgen-independent prostate cancer. Cancer Res 2006, 66(I): 175-183.

18. Haudenschild DR, Palmer SM, Moseley TA, You Z, Reddi AH: Bone morphogenetic protein (BMP)-6 signaling and BMP antagonist noggin in prostate cancer. Cancer Res 2004, 64(22):8276-8284.

19. Nesslinger NJ, Shi XB, deVere White RW: Androgen-independent growth of LNCaP prostate cancer cells is mediated by gainof-function mutant p53. Cancer Res 2003, 63(9):2228-2233.

20. You Z, Ouyang H, Lopatin D, Polver PJ, Wang CY: Nuclear factorkappa B-inducible death effector domain-containing protein suppresses tumor necrosis factor-mediated apoptosis by inhibiting caspase-8 activity. I Biol Chem 200I, 276(28):26398-26404.
21. Lin YZ, Yao SY, Veach RA, Torgerson TR, Hawiger J: Inhibition of nuclear translocation of transcription factor NF-kappa B by a synthetic peptide containing a cell membrane-permeable motif and nuclear localization sequence. I Biol Chem 1995, 270(24): 14255-14258.

22. Owada K, Sanjyo N, Kobayashi T, Kamata T, Mizusawa H, Muramatsu $\mathrm{H}$, Muramatsu T, Michikawa M: Midkine inhibits apoptosis via extracellular signal regulated kinase (ERK) activation in PCI 2 cells. J Med Dent Sci 1999, 46(I):45-5I.

23. Muramatsu T: Midkine and pleiotrophin: two related proteins involved in development, survival, inflammation and tumorigenesis. J Biochem (Tokyo) 2002, I 32(3):359-37I.

24. Kaplan F, Comber J, Sladek R, Hudson TJ, Muglia LJ, Macrae T, Gagnon S, Asada M, Brewer JA, Sweezey NB: The growth factor midkine is modulated by both glucocorticoid and retinoid in fetal lung development. Am J Respir Cell Mol Biol 2003, 28(I):33-4I.

25. Reynolds PR, Mucenski ML, Le Cras TD, Nichols WC, Whitsett JA: Midkine is regulated by hypoxia and causes pulmonary vascular remodeling. J Biol Chem 2004, 279(35):37/24-37I32.

26. Yuki T, Ishihara S, Rumi M, Ortega-Cava Cesar F, Kadowaki Y, Kazumori H, Yuki M, Wada T, Miyaoka Y, Yoshino N, Kinoshita Y: Expression of midkine and receptor-like protein tyrosine phosphatase (RPTP)-beta genes in the rat stomach and the influence of rebamipide. Aliment Pharmacol Ther 2003, I 8 Suppl I:I06-II 2.

27. Zhou J, Jin Y, Gao Y, Wang H, Hu G, Huang Y, Chen Q, Feng M, Wu $\mathrm{C}$ : Genomic-scale analysis of gene expression profiles in TNF-alpha treated human umbilical vein endothelial cells. Inflamm Res 2002, 5 I (7):332-34I.

28. Uehara K, Matsubara S, Kadomatsu K, Tsutsui J, Muramatsu T: Genomic structure of human midkine (MK), a retinoic acidresponsive growth/differentiation factor. I Biochem (Tokyo) 1992, II I(5):563-567.

29. Lin J, Adam RM, Santiestevan E, Freeman MR: The phosphatidylinositol 3'-kinase pathway is a dominant growth factor-activated cell survival pathway in LNCaP human prostate carcinoma cells. Cancer Res 1999, 59(12):2891-2897.

30. Luschen S, Scherer G, Ussat S, Ungefroren H, Adam-Klages S: Inhibition of p38 mitogen-activated protein kinase reduces TNFinduced activation of NF-kappaB, elicits caspase activity, and enhances cytotoxicity. Exp Cell Res 2004, 293(2): 196-206.

31. Ricote M, Garcia-Tunon I, Bethencourt F, Fraile B, Onsurbe P, Paniagua $R$, Royuela $M$ : The $p 38$ transduction pathway in prostatic neoplasia. The Journal of pathology 2006, 208(3):40I-407.

32. Maroni PD, Koul S, Meacham RB, Koul HK: Mitogen Activated Protein kinase signal transduction pathways in the prostate. Cell Commun Signal 2004, 2(I):5.

33. Kulik G, Carson JP, Vomastek T, Overman K, Gooch BD, Srinivasula $S$, Alnemri E, Nunez G, Weber MJ: Tumor necrosis factor alpha induces BID cleavage and bypasses antiapoptotic signals in prostate cancer LNCaP cells. Cancer Res 200 I, 6 I(6):27 I3-27I9.

34. Sastry KSR, Karpova Y, Kulik G: Epidermal Growth Factor Protects Prostate Cancer Cells from Apoptosis by Inducing BAD Phosphorylation via Redundant Signaling Pathways. J Biol Chem 2006, 28 I (37):27367-27377.

35. Horiba M, Kadomatsu K, Yasui K, Lee JK, Takenaka $H$, Sumida A Kamiya K, Chen S, Sakuma S, Muramatsu T, Kodama I: Midkine plays a protective role against cardiac ischemia/reperfusion injury through a reduction of apoptotic reaction. Circulation 2006, II 4(16): $1713-1720$

36. Michalaki V, Syrigos K, Charles P, Waxman J: Serum levels of IL-6 and TNF-alpha correlate with clinicopathological features and patient survival in patients with prostate cancer. Br J Cancer 2004, 90(| 2):23|2-23|6

37. Top C, Tuncel A, Öncül O, Özkan S, Koçak N, Çavuslu S, Danaci M: The Correlation Of Insulin Resistance With Serum TNF- $\alpha$ Levels In Patients With Rheumatoid Artritis. The Internet Journal of Rheumatology 2002, I(I):

38. Diez J], Hernanz A, Medina S, Bayon C, Iglesias P: Serum concentrations of tumour necrosis factor-alpha (TNF-alpha) and soluble TNF-alpha receptor $\mathrm{p55}$ in patients with hypothyroidism and hyperthyroidism before and after normalization of thyroid function. Clinical endocrinology 2002, 57(4):5 I 5-52 I.

39. Jablonska E, Piotrowski L, Grabowska Z: Serum Levels of IL-Ib, IL-6, TNF-a, sTNF-RI and CRP in Patients with Oral Cavity Cancer. Pathol Oncol Res 1997, 3(2): I26-129. 
40. Briscoe H, Roach DR, Meadows N, Rathjen D, Britton W]: A novel tumor necrosis factor (TNF) mimetic peptide prevents recrudescence of Mycobacterium bovis bacillus CalmetteGuerin (BCG) infection in CD4+ T cell-depleted mice. Journal of Leukocyte Biology 2000, 68(4):538-544.

4I. Pang XP, Yoshimura M, Hershman JM: Suppression of rat thyrotroph and thyroid cell function by tumor necrosis factoralpha. Thyroid 1993, 3(4):325-330.

42. Muramaki M, Miyake H, Hara I, Kamidono S: Introduction of midkine gene into human bladder cancer cells enhances their malignant phenotype but increases their sensitivity to antiangiogenic therapy. Clin Cancer Res 2003, 9(14):5I52-5I60.

43. Takei $Y$, Kadomatsu K, Goto T, Muramatsu T: Combinational antitumor effect of siRNA against midkine and paclitaxel on growth of human prostate cancer xenografts. Cancer 2006, 107(4):864-873.

\section{Pre-publication history}

The pre-publication history for this paper can be accessed here:

http://www.biomedcentral.com/1755-8794/1/6/prepub

Publish with Biomed Central and every scientist can read your work free of charge

"BioMed Central will be the most significant development for disseminating the results of biomedical research in our lifetime. "

Sir Paul Nurse, Cancer Research UK

Your research papers will be:

- available free of charge to the entire biomedical community

- peer reviewed and published immediately upon acceptance

- cited in PubMed and archived on PubMed Central

- yours - you keep the copyright

Submit your manuscript here:

http://www.biomedcentral.com/info/publishing_adv.asp
BiolMedcentral 